\title{
Antibody response to pneumococcal capsular polysaccharide vaccine in Down syndrome patients
}

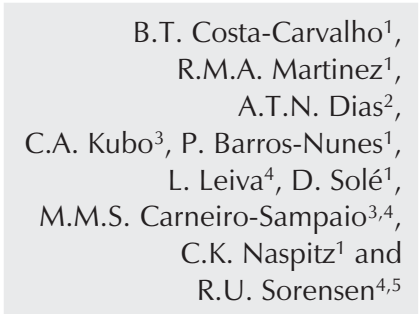

Correspondence

B.T. Costa-Carvalho

Rua Jacques Felix, 314, Apto. 31

04509-001 São Paulo, SP

Brasil

Fax: +55-11-5579-1590

E-mail: beacarvalho@terra.com.br

Research supported by FAPESP.

Received February 21, 2006

Accepted August 24, 2006

\author{
${ }^{1}$ Disciplina de Alergia, Imunologia Clínica e Reumatologia, \\ Departamento de Pediatria, Escola Paulista de Medicina, \\ Universidade Federal de São Paulo, São Paulo, SP, Brasil \\ ${ }^{2}$ Departamento de Toxicologia e Análises Clínicas, \\ Universidade Federal do Ceará, Fortaleza, CE, Brasil \\ ${ }^{3}$ Departamento de Imunologia, Instituto de Ciências Biomédicas, \\ Universidade de São Paulo, São Paulo, SP, Brasil \\ ${ }^{4}$ Departamento de Pediatria, Faculdade de Medicina, LIM 36, \\ Universidade de São Paulo, São Paulo, SP, Brasil \\ ${ }^{5}$ Department of Pediatrics, Louisiana State University Health Science Center, \\ New Orleans, LA, USA
}

\section{Abstract}

The majority of children with Down syndrome (DS) tend to have frequent bacterial infections including recurrent respiratory infections. Our objective was to evaluate the production of antibodies to pneumococcal polysaccharide antigens after active immunization in DS subjects. IgG antibodies to pneumococcal serotypes $(1,3,6 \mathrm{~B}, 9 \mathrm{~V}$, and 14) were measured before and 6 weeks after immunization with a 23-valent pneumococcal vaccine (Pneumo23 ${ }^{\circledR}$, Pasteur-Merrieux) in 6- to 13-year-old DS children $(\mathrm{N}=17)$ and in aged-matched normal controls $(\mathrm{N}=30)$. An adequate response was defined as a 4 -fold increase over baseline or a post-immunization level of specific pneumococcal serotype antibody $\geq 1.3 \mu \mathrm{g} / \mathrm{mL}$. After immunization, all DS children had an increase in post-immunization levels against all serotypes analyzed. A 4-fold or more increase was observed in all DS children concerning serotypes 1 and 14, in $90 \%$ of subjects for serotypes 3 and $9 \mathrm{~V}$, and in 65\% for serotype 6B. Regarding this increase, 8 of the 17 DS children had an adequate response to all serotypes analyzed, $8 / 17$ patients to 4 serotypes and $1 / 17$ to 3 serotypes. However, when we compared post-immunization levels between DS children and controls, we observed lower levels in the former group $(\mathrm{P}<0.05)$ for all serotypes except serotype 3 . We conclude that pneumococcal polysaccharide immunization could be beneficial for these DS children.

\section{Introduction}

Down syndrome (DS) is the most common trisomy in liveborn children and the major known genetic cause of mental retar-
Key words

- Down syndrome

- Immunoglobulin

- IgG subclass

- Polysaccharide vaccine

- Streptococcus pneumoniae

- Pneumococcal antibodies dation (1). The incidence of DS in Latin American countries is approximately $1 / 700$ live births (2). Despite advancements in treatment, pneumonia and other respiratory diseases are still the major causes of morbidity 
and mortality in DS children (3). Different aspects of the immune system have been studied in DS to obtain a better understanding of the increased risk of infection observed in affected individuals (4). Abnormalities in humoral and cell-mediated immunities and in phagocytic function have been reported (3-7).

Data concerning post-immunization antibody production in DS patients are variable. Antibody production to tetanus toxoid and influenza virus is decreased or normal $(8,9)$, and isohemagglutinin titers and natural antibodies to Escherichia coli are normal (10). The antibody response to bacteriophage $\varnothing \mathrm{X} 174$ is impaired both in primary and secondary immunological responses (11). These facts argue for an impaired humoral response in DS patients. Polysaccharides are considered to be T-independent antigens and immunization with polysaccharide vaccines has been recommended as a diagnostic tool to evaluate patient ability to respond to those antigens (12). Nurmi et al. (13) observed a lower response to polysaccharide antigens in adult DS patients compared to controls. In the present study, we evaluated pneumococcal serotype antibodies before and after immunization with a 23-valent pneumococcal polysaccharide vaccine (Pneumo23 ${ }^{\circledR}$ ) in DS children.

\section{Subjects and Methods}

Seventeen non-institutionalized 6- to 13year-old DS subjects attending a daily facility for mentally handicapped children (APAEAssociação dos Pais e Amigos dos Excepcionais, São Paulo) were studied (10 girls and 7 boys). None of them had a history of recurrent infections or cardiovascular malformations. Thirty age-matched healthy children living in the same area of São Paulo served as controls. All children were submitted to clinical examination and peripheral blood samples were obtained from each patient to quantify the levels of immunoglobulin (Ig; G, A, M), of IgG subclasses and of antibodies against polysaccharide pneumococcal serotypes 1, 3, 6B, 9V, and 14 .

Anti-pneumococcal IgG antibodies against pneumococcal serotypes $1,3,6 \mathrm{~B}, 9 \mathrm{~V}$, and 14 were determined using a modified ELISA protocol $(14,15)$. Standard, control and DS children's serum samples were pre-absorbed for $30 \mathrm{~min}$ at $37^{\circ} \mathrm{C}$ with Streptococcus pneumoniae C-polysaccharide $(500 \mu \mathrm{g} / \mathrm{mL}$ in undiluted serum; Statens Serum Institut, Copenhagen, Denmark). The serotype-specific IgG antibody concentration $(\mu \mathrm{g} / \mathrm{mL})$ was calculated using a standard curve obtained for a serum pool that had been previously calibrated using the FDA 89-SF reference sample (CBER, U.S. Food and Drug Administration, Rockville, MD, USA).

Serum samples were collected before and 6 weeks after immunization with the 23valent pneumococcal capsular polysaccharide vaccine (Pneumo23 ${ }^{\circledR}$ Pasteur-Merrieux, Marcyl Etoile, Lyon, France). An adequate response to individual polysaccharide was arbitrarily defined as a post-immunization antibody concentration equal to or higher than $1.3 \mu \mathrm{g} / \mathrm{mL}$ or a minimum 4-fold increase over the baseline value $(14,15)$.

The Wilcoxon test was applied to compare pre- and post-IgG anti-pneumococcal serotype levels in DS patients, and the MannWhitney test was used to compare these antibodies between DS children and controls. The study was approved by APAE and by the UNIFESP-EPM Ethics Committee. The parents of the children participating in the study gave a written informed consent.

\section{Results}

Normal serum IgA and IgM levels were observed in DS children. Compared to normal values, all DS children but one had a serum IgG level above the 97th percentile, and 8/17 of them had IgG levels higher than 2,000 mg/ dL. DS children showed a tendency to higher levels of serum IgG1 and IgG3 compared to controls. In 13 of 17 and in 12 of 17 DS 
children, IgG1 and IgG3 levels were higher than the 97th percentile, respectively. In contrast, serum IgG2 levels below the 50th percentile were observed in 15/17 (88\%) subjects. Two DS children had serum IgG2 levels below the 3 rd percentile associated with $\mathrm{IgG} 4$ deficiency and they did not have any recurrent infections. Almost 53\% of DS children had undetectable serum IgG4 levels.

Compared to controls, pre-immunization antibody levels to pneumococcus were significantly lower in DS children for all serotypes evaluated and both groups showed a significant increase of post-immunization compared with pre-immunization levels (Table 1). A 4-fold or more increase was observed in all subjects for serotypes 1 and 14 , in $90 \%$ of subjects for serotypes 3 and $9 \mathrm{~V}$, and in $65 \%$ for serotype $6 \mathrm{~B}$. Controls had an adequate production of antibodies to all serotypes. The mean increase (post/preratio) of IgG anti-pneumococcal serotype antibodies was higher than 7 for DS children, except for serotype 3 (Table 1, Figure 1). On
Table 1. Mean pre- and post-immunization (Pneumo23 ${ }^{\circledR}$ ) antibody levels and post/ pre-ratio in children with Down syndrome $(\mathrm{N}=17)$ and age-matched controls $(\mathrm{N}=30)$.

\begin{tabular}{|c|c|c|c|c|c|c|}
\hline \multirow[b]{2}{*}{ Serotype } & \multicolumn{3}{|c|}{ Down syndrome } & \multicolumn{3}{|c|}{ Controls } \\
\hline & Pre- & Post- & $\begin{array}{c}\text { Post/pre- } \\
\text { ratio }\end{array}$ & Pre- & Post- & $\begin{array}{c}\text { Post/pre- } \\
\text { ratio }\end{array}$ \\
\hline $1 \mathrm{GM}$ & 0.20 & $1.54^{*}$ & $10.9^{* *}$ & 1.20 & $2.91^{*+}$ & 2.4 \\
\hline $95 \% \mathrm{Cl}$ & $0.13-0.54$ & $1.35-2.87$ & & $0.72-4.98$ & $2.64-7.19$ & \\
\hline 3 GM & 0.66 & $1.94^{*}$ & $3.7^{\star \star}$ & 1.49 & $1.98^{*}$ & 1.3 \\
\hline $95 \% \mathrm{Cl}$ & $0.42-1.99$ & $1.65-2.86$ & & $1.46-2.87$ & $1.92-3.31$ & \\
\hline 6B GM & 0.25 & $1.29^{*}$ & $8.9^{\star *}$ & 1.71 & $4.38^{*+}$ & 2.6 \\
\hline $95 \% \mathrm{Cl}$ & $0.17-0.57$ & $0.82-3.78$ & & $1.73-5.1$ & $3.79-15.4$ & \\
\hline 9V GM & 0.17 & $1.28^{\star}$ & $9.9^{\star \star}$ & 1.00 & $2.66^{*+}$ & 2.7 \\
\hline $95 \% \mathrm{Cl}$ & $0.12-0.4$ & $0.84-2.95$ & & $0.68-3.46$ & $2.42-5.68$ & \\
\hline 14 GM & 0.78 & $3.53^{\star}$ & $7.3^{\star \star}$ & 2.01 & $9.54^{\star+}$ & 4.7 \\
\hline $95 \% \mathrm{Cl}$ & $0.65-1.87$ & $1.93-12.8$ & & $2.16-4.29$ & $6.9-37.84$ & \\
\hline
\end{tabular}

Data are reported as means and range. $\mathrm{GM}=$ geometric mean; $95 \% \mathrm{Cl}=95 \%$ confidence interval.

${ }^{*} \mathrm{P}<0.001=$ post $>$ pre. ${ }^{* *} \mathrm{P}<0.001=$ Down syndrome $>$ controls post/pre-ratio Down syndrome vs control. ${ }^{+} \mathrm{P}<0.05=$ post-control $>$ post-Down syndrome (Wilcoxon and Mann-Whitney tests).

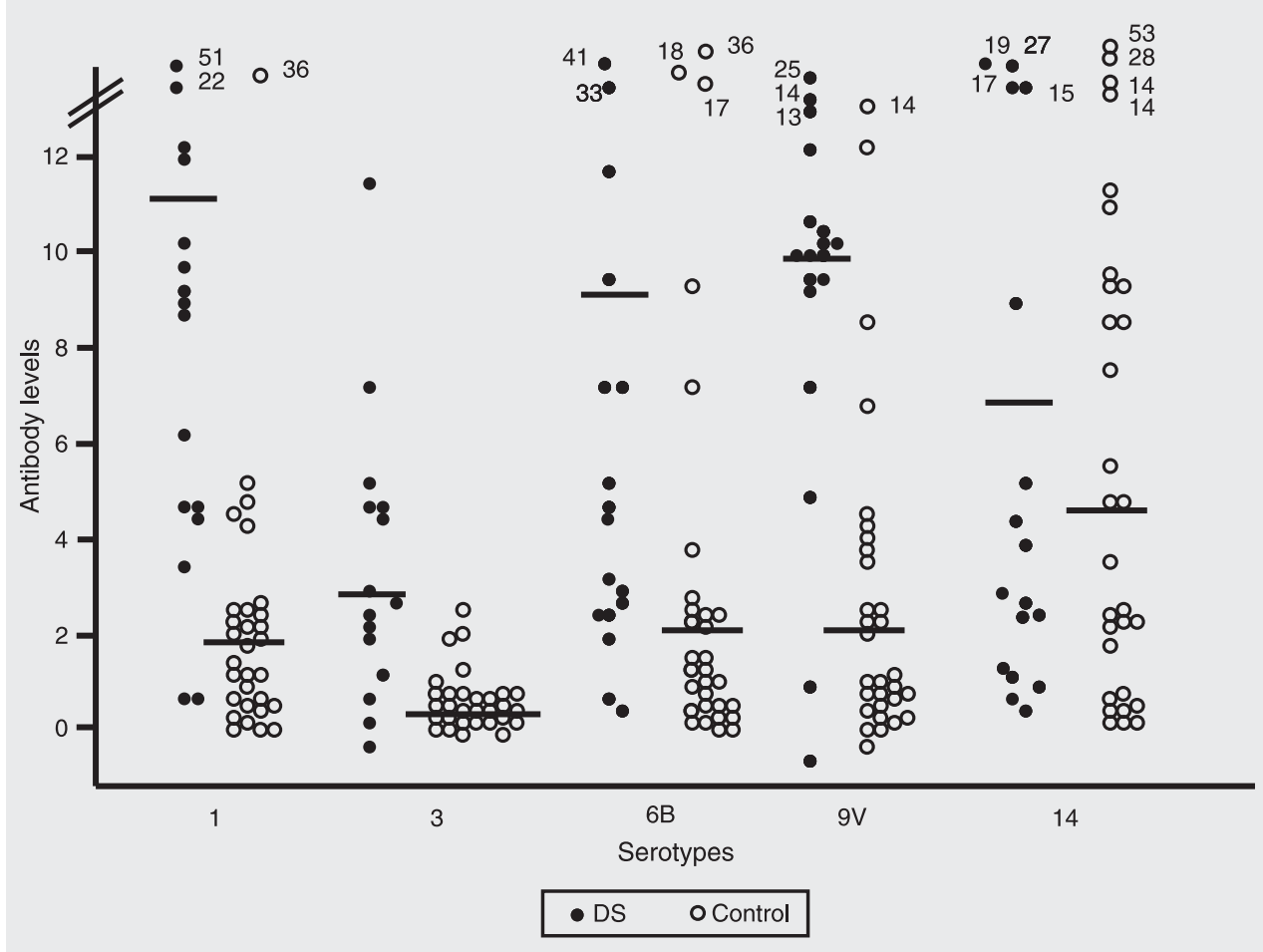

Figure 1. Comparison of the increase of antibody levels after immunization (Pneumo23 ${ }^{\circledR}$ ) for serotypes $1,3,6 \mathrm{~B}, 9 \mathrm{~V}$, and 14 in Down syndrome children ( $\mathrm{N}$ $=17)$ and controls $(\mathrm{N}=30)$. The numbers next to the symbols refer to the individual increase. Statistical comparisons are given in Table 1. 
the basis of the increase, eight of the 17 DS children had an adequate response to all serotypes analyzed, $8 / 17$ patients to 4 serotypes and $1 / 17$ to 3 serotypes. However, when we compared post-immunization levels between DS children and controls, we observed lower levels in the former group $(\mathrm{P}<0.05)$ to all serotypes except serotype 3 (Table 1). No DS child had levels of antipneumococcal $\mathrm{IgG}$ equal to or higher than $1.3 \mu \mathrm{g} / \mathrm{mL}$ for serotypes 1 and 9 pre- or postimmunization. Three DS children presented levels equal to or higher than $1.3 \mu \mathrm{g} / \mathrm{mL}$ for serotype 3, 1/17 DS children for serotype 6B, and 6/17 DS children for serotype 14 .

DS children showed a significantly elevated post/pre ratio compared to controls (Table 1). Two DS children with IgG2 deficiency had an appropriate response to the 23-valent pneumococcal polysaccharide vaccine.

\section{Discussion}

It is well recognized that DS children have increased susceptibility to infections, mainly respiratory ones. They also have an increased risk of leukemias and other malignancies, as well as a higher incidence of auto-antibodies. A number of immunologic abnormalities have been noted in DS children although most of them have no clear immune dysfunction (3-5). Pneumococcal vaccines have been recommended to groups of patients who are at high risk, or who experience severe or frequent diseases (16).

Increased serum IgG levels and decreased IgM levels have been reported in DS children in late childhood and adolescence (6), as well as an increase of these immunoglobulins in saliva (17). Our DS children had increased serum IgG levels compared to controls, reflecting an overstimulation of B lymphocytes mainly due to $\operatorname{IgG} 1$ and $\mathrm{IgG} 3$ isotypes since these levels were elevated in the majority of DS children. High serum levels of IgG1 and IgG3 have been reported in DS adults (18). Despite their high IgG levels, DS children have been recently shown to present a lower number of B lymphocytes compared to controls throughout childhood (19).

In adults, anti-polysaccharide antibodies are found mainly with IgM and IgG2 isotypes (20). A normal IgM level and a tendency to lower levels of $\mathrm{IgG} 2$ were observed in our DS children, in agreement with other reports (18). Two DS children, aged 8 and 10 years, had serum IgG2 levels below the 3rd percentile but showed an adequate increase of pneumococcal antibodies after immunization. Subnormal serum IgG2 levels do not necessarily reflect a functional immunodeficiency $(21,22)$. An adequate response to pneumococcal antigens depends on an interaction between innate and adaptive immune responses. An inefficient release of mature $\mathrm{T}$ cells from the DS thymus to the spleen leads to decreased education of $\mathrm{B}$ cells by $\mathrm{T}$ cells which could explain the diminished antibody responses of DS B cells to bacterial and viral antigens (4). However, polysaccharide antigens are considered to be thymus-independent and repeated epitopes expressed by polysaccharides induce multivalent membrane immunoglobulin crosslinking on the B-cell surface resulting in activation and proliferation of theses cells (23).

A normal IgG antibody response to pneumococcal immunization has not been well defined but a 2- to 4-fold rise in antibody levels post-immunization generally reflects an adequate response. Several other variables should also be considered, i.e., the protective level may depend on the age of the individual and may differ for different pneumococcal serotypes (24-26). There is a delay in the ontogeny of the acquisition of the polysaccharide antigen response, which involves very poor immunogens for infants $(27,28)$. A specific antibody response to polysaccharide antigens is complete in children over 2 years of age $(24,29)$. Our DS 
children were older than 5 years and had a significant increase in the levels of antibodies to all serotypes evaluated after immunization, although these levels were lower than those observed in controls. In spite of lower levels compared to normal controls, DS children showed a 7-fold mean increase in antibodies which suggests that they produced pneumococcal antibodies after immunization and that probably this vaccine could offer some protection for them.

In Brazil, the most prevalent pneumococcal serotypes isolated from invasive infections are 1, 5, 6, and $14(30,31)$ and the serotype distribution for invasive pneumococcal diseases is age-related (32). Pre-immunization levels of serotype 14 antibody were higher than $1.3 \mu \mathrm{g} / \mathrm{mL}$ in $6 / 17$ of our DS children, suggesting previous contact. However, the other serotypes were observed in only a few patients and their mean levels were significantly lower than those of normal controls. It was presumed that the DS children and normal controls were exposed to the same pneumococcal serotypes because they lived in the same city and were of similar socioeconomic status. Similar results were observed by others in DS adults and controls living in the same area (13).

The CDC's Advisory Committee on Im- munization Practices (ACIP) had previously recommended 23-valent pneumococcal polysaccharide vaccines for use among children over 2 years of age who had a high risk of pneumococcal disease, including those with chronic underlying diseases or who were immunocompromised. Today the ACIP recommends the new 7-valent pneumococcal conjugate vaccine (33). Although the conjugate vaccine has many advantages, it is very expensive and includes only 7 serotypes. Serotypes 1 and 5, which are not present in this vaccine, remain among the principal serotypes in Brazil, mainly in children with pneumonia (32). The polysaccharide vaccine may be an alternative for these patients over 2 years old in developing countries.

We conclude that DS children present an adequate increase of antibody levels after the pneumococcal polysaccharide vaccine and that they could derive some benefit from this vaccine.

\section{Acknowledgments}

We wish to thank APAE (Associação dos Pais e Amigos dos Excepcionais, São Paulo, SP, Brazil) and all the families who have collaborated with this study.

\section{References}

1. Hassold TJ, Jacobs PA. Trisomy in man. Annu Rev Genet 1984; 18 : 69-97.

2. Castilla EE, Orioli IM. ECLAMC: the Latin-American collaborative study of congenital malformations. Community Genet 2004; 7: 7694 .

3. Ugazio AG, Maccario R, Notarangelo LD, Burgio GR. Immunology of Down syndrome: a review. Am J Med Genet Supp/ 1990; 7: 204212.

4. Murphy M, Insoft RM, Pike-Nobile L, Epstein LB. A hypothesis to explain the immune defects in Down syndrome. Prog Clin Biol Res 1995; 393: 147-167.

5. Burgio GR, Ugazio AG, Nespoli L, Maccario R. Down syndrome: A model of immunodeficiency. Birth Defects 1983; 19: 325-327.

6. Lockitch G, Singh VK, Puterman ML, Godolphin WJ, Sheps S, Tingle AJ, et al. Age-related changes in humoral and cell-mediated immunity in Down syndrome children living at home. Pediatr Res
1987; 22: 536-540.

7. Loh RK, Harth SC, Thong YH, Ferrante A. Immunoglobulin G subclass deficiency and predisposition to infection in Down's syndrome. Pediatr Infect Dis J 1990; 9: 547-551.

8. Gordon MC, Sinha SK, Carlson SD. Antibody responses to influenza vaccine in patients with Down's syndrome. Am J Ment Defic 1971; 75: 391-399.

9. Griffiths AW, Sylvester PE. Mongols and non-mongols compared in their response to active tetanus immunisation. J Ment Defic Res 1967; 11: 263-266.

10. Adinolfi M, Gardner B, Martin W. Observations on the levels of gamma G, gamma A, gamma M globulins, anti-A and anti-B agglutinins, and antibodies to Escherichia coli in Down's anomaly. J Clin Pathol 1967; 20: 860-864.

11. Lopez V, Ochs HD, Thuline HC, Davis SD, Wedgwood RJ. Defective antibody response to bacteriophage phichi 174 in Down syn- 
drome. J Pediatr 1975; 86: 207-211.

12. Zielen S, Buhring I, Ewald F, Ahrens $P$, Hofmann D. Immunoglobulin subclasses and polysaccharide specific immuno-deficiency states in patients with recurrent respiratory infections. Pediatr Pulmonol Suppl 1997; 16: 146-147.

13. Nurmi T, Leinonen M, Haiva VM, Tiilikainen A, Kouvalainen $K$. Antibody response to pneumococcal vaccine in patients with trisomy-21 (Down's syndrome). Clin Exp Immunol 1982; 48: 485-490.

14. Sorensen RU, Hidalgo $\mathrm{H}$, Moore $\mathrm{C}$, Leiva LE. Post-immunization pneumococcal antibody titers and IgG subclasses. Pediatr Pulmonol 1996; 22: 167-173.

15. Sorensen RU, Leiva LE, Javier FC III, Sacerdote DM, Bradford N, Butler B, et al. Influence of age on the response to Streptococcus pneumoniae vaccine in patients with recurrent infections and normal immunoglobulin concentrations. J Allergy Clin Immunol 1998; 102: 215-221.

16. Posfay-Barbe KM, Wald ER. Pneumococcal vaccines: do they prevent infection and how? Curr Opin Infect Dis 2004; 17: 177-184.

17. Chaushu S, Yefe NE, Becker A, Shapira J, Chaushu G. Parotid salivary immunoglobulins, recurrent respiratory tract infections and gingival health in institutionalized and non-institutionalized subjects with Down's syndrome. J Intellect Disabil Res 2003; 47: 101-107.

18. Anneren G, Magnusson CG, Lilja G, Nordvall SL. Abnormal serum IgG subclass pattern in children with Down's syndrome. Arch Dis Child 1992; 67: 628-631.

19. de Hingh YC, van der Vossen PW, Gemen EF, Mulder AB, Hop WC, Brus $F$, et al. Intrinsic abnormalities of lymphocyte counts in children with Down syndrome. J Pediatr 2005; 147: 744-747.

20. Barrett DJ, Ayoub EM. IgG2 subclass restriction of antibody to pneumococcal polysaccharides. Clin Exp Immunol 1986; 63: 127134.

21. Shackelford PG, Granoff DM, Madassery JV, Scott MG, Nahm MH. Clinical and immunologic characteristics of healthy children with subnormal serum concentrations of IgG2. Pediatr Res 1990; 27: 1621.

22. Costa Carvalho BT, Nagao AT, Arslanian C, Carneiro Sampaio MM, Naspitz CK, Sorensen RU, et al. Immunological evaluation of allergic respiratory children with recurrent sinusitis. Pediatr Allergy Immunol 2005; 16: 534-538.

23. Casal J, Tarrago D. Immunity to Streptococcus pneumoniae: Factors affecting production and efficacy. Curr Opin Infect Dis 2003; 16:
219-224.

24. Douglas RM, Paton JC, Duncan SJ, Hansman DJ. Antibody response to pneumococcal vaccination in children younger than five years of age. $J$ Infect Dis 1983; 148: 131-137.

25. Paton JC, Toogood IR, Cockington RA, Hansman D. Antibody response to pneumococcal vaccine in children aged 5 to 15 years. Am J Dis Child 1986; 140: 135-138.

26. Balmer P, North J, Baxter D, Stanford E, Melegaro A, Kaczmarski $\mathrm{EB}$, et al. Measurement and interpretation of pneumococcal IgG levels for clinical management. Clin Exp Immunol 2003; 133: 364369.

27. Claesson BA, Lagergard T, Trollfors B. Development of serum antibodies of the immunoglobulin $\mathrm{G}$ class and subclasses against the capsular polysaccharide of Haemophilus influenzae type $\mathrm{b}$ in children and adults with invasive infections. J Clin Microbiol 1988; 26 : 2549-2553.

28. IshigamiMiyake TT, Nagao AT, Arslanian C, Harima HA, CostaCarvalho BT, Carneiro-Sampaio MM, et al. Evaluation of serum levels of IgG subclasses and anti-ribosyl-ribitolphosphate IgG and IgG2 in children with Haemophilus influenzae b meningitis. J Trop Pediatr 1999; 45: 130-134.

29. Dizon JG, Goldberg BJ, Kaplan MS. How to evaluate suspected immunodeficiency. Pediatr Ann 1998; 27: 743-750.

30. Brandileone MC, Vieira VS, Casagrande ST, Zanella RC, Guerra $\mathrm{ML}$, Bokermann S, et al. Prevalence of serotypes and antimicrobial resistance of Streptococcus pneumoniae strains isolated from Brazilian children with invasive infections. Pneumococcal Study Group in Brazil for the SIREVA Project. Regional System for Vaccines in Latin America. Microb Drug Resist 1997; 3: 141-146.

31. Taunay AE, Austrian R, Landgraf IM, Vieira MF, Melles CE. Serotypes of Streptococcus pneumoniae isolated from cerebrospinal fluid in 1977-1988 in São Paulo city, Brazil. Rev Inst Med Trop São Paulo 1990; 32: 11-15.

32. Brandileone MC, de Andrade AL, Di Fabio JL, Guerra ML, Austrian R. Appropriateness of a pneumococcal conjugate vaccine in Brazil: potential impact of age and clinical diagnosis, with emphasis on meningitis. J Infect Dis 2003; 187: 1206-1212.

33. Advisory Committee on Immunization Practices (ACIP). Preventing pneumococcal disease among infants and young children. MMRW Recomm Rep 2000; 49: 1-38. 